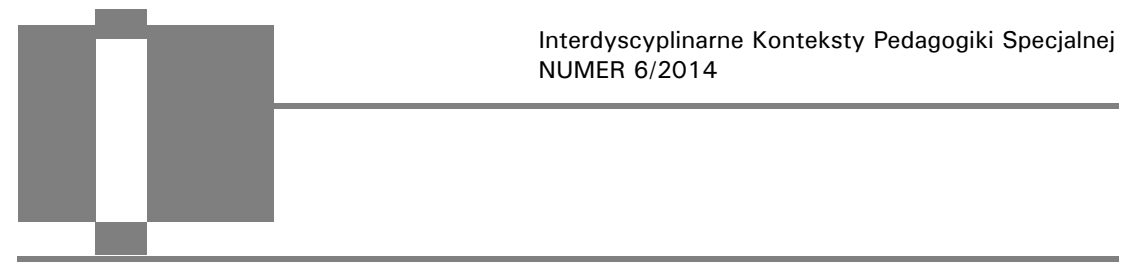

\title{
Agnieszka Wątorek, Kompetencje językowe dzieci z lekką niepełnosprawnością intelektualną, Zakład Wydawniczy NOMOS, Kraków 2014
}

Publikacja zatytułowana Kompetencje jezzykowe dzieci z lekka niepetnosprawnościq intelektualna autorstwa Agnieszki Wątorek poświęcona jest mowie jako jednemu z aspektów rozwoju dzieci. Publikacja przedstawia wyniki badań własnych autorki nad kompetencją językową dzieci z diagnozą lekkiego upośledzenia umysłowego. W pracy dokonano syntezy treści powiązanych z różnymi dyscyplinami naukowymi (językoznawstwa, psycholingwistyki oraz pedagogiki specjalnej). Jak twierdzi autorka, publikacja przeznaczona jest dla wszystkich zainteresowanych problemami dzieci z lekką niepełnosprawnością intelektualną.

Autorka książki jest doktorem nauk humanistycznych w zakresie językoznawstwa, absolwentką Uniwersytetu Pedagogicznego w Krakowie (pedagogika specjalna, logopedia, nowoczesne kierowanie oświatą i zarządzanie oświatą), Szkoły Wyższej Psychologii Społecznej w Warszawie (neurologopedia) oraz Uniwersytetu Jagiellońskiego (językoznawstwo studia III stopnia). W swojej pracy naukowej zajmuje się edukacją, terapią i wspieraniem aktywności twórczej uczniów z lekką niepełnosprawnością intelektualną. Jest animatorką działalności artystycznej dzieci z lekką niepełnosprawnością intelektualną, autorką scenariuszy sztuk teatralnych dla najmłodszych oraz współorganizatorką imprez kulturalnych służących integracji dzieci niepełnosprawnych ze środowiskiem lokalnym. Przedstawiana publikacja nie jest jedyną w dorobku autorki. W 2006 r. opubliko- 
wano zbiór scenariuszy do przedstawień szkolnych pt. Dialogi wierszem pisane na okazje wciąż te same.

Książka składa się z siedmiu rozdziałów, które można podzielić na dwie części: pierwszą odnoszącą się do definiowania pojęć kompetencji językowej oraz wyjaśnienia związku pomiędzy kompetencją poznawczą i językową w kontekście LNI oraz część drugą przedstawiającą metodologię oraz wyniki badań własnych autorki. Publikację rozpoczyna krótki wstęp, w którym autorka przedstawia plan książki i opisuje zawartość każdego rozdziału. Na końcu wstępu autorka składa podziękowania pani doc. Magdalenie Smoczyńskiej za pomoc w zaprojektowaniu badań nad kompetencją językową, recenzentom książki za cenne uwagi, a także dyrektorom szkól, nauczycielom i rodzicom za możliwość przeprowadzenia badań.

Pierwszą część publikacji otwiera rozdział pt. Kompetencja językowa pojęcie, ortogeneza, sposoby $i$ badania. W rozdziale tym objaśniono termin "kompetencja językowa”, przedstawiono etapy ich nabywania w prawidłowym rozwoju oraz przyczyny niepowodzeń. Autorka prezentuje pojęcie kompetencji językowej w dwojaki sposób, odnosząc się do źródeł naukowych i definicji przedstawionej przez Noama Chomsky' ego, która przez dekady inspirowała badaczy. Sięga do najnowszych definicji psycholingwistyki na gruncie polskich badań naukowych. Powołuje się na publikacje Idy Kurcz i Stanisława Grabiasa. W podrozdziale drugim Agnieszka Wątorek opisuje proces nabywania kompetencji językowej w warunkach prawidłowego rozwoju. Przedstawia proces nabywania języka od okresu płodowego do okresu wczesnoszkolnego oraz kierunki nabywania słownictwa przez dzieci. Na podstawie najnowszych badań ukazuje grupe czynników mających wpływa na rozwój mowy dziecka. Obok czynników genetycznych pojawił się także czynnik społeczny i pojęcie „dzieci wilczych" - dzieci żyjących w izolacji społecznej, sierocińcach i domach dziecka. Opisuje zaburzenia języka u dzieci i związane z nimi dysfunkcje rozwojowe. Rozdział kończą koncepcje metodologiczne $w$ badaniach nad kompetencją językową. Autorka przedstawia narzędzia diagnostyczny w badaniach nad zaburzeniami mowy, metody ilościowe i jakościowe służące do szacowania wielkości słownika biernego i czynnego. Przedstawia sposoby diagnozowania słownictwa przy użyciu testów psychologicznych. Prezentuje trzy rodzaje testów stosowanych do oceny słownictwa dzieci, są to: TSD - Test Słownikowy dla dzieci w wieku od 4 do 7 lat Marty Koć- 
-Januchty, OTS-R - Obrazkowy Test Słownikowy - rozumienie Ewy Haman i Krzysztofa Fronczyka stosowany dla dzieci w wieku 2;0-6;11, a także Test Językowy LEKSYKON Andrzeja Jurkowskiego przeznaczony do badań młodzieży 12;6-17;5. Odnosi się on do koncepcji kategorii semantycznych Herberta Clarka i Eleanor Rosch oraz hipotezy funkcjonalnego jądra Katherine Nelson. Przedstawia metody i techniki badania umiejętności gramatycznych i wypowiedzi narracyjnych.

W rozdziale 2 zatytułowanym Zwiazek pomiędzy kompetencja poznawcza $i$ językowa w kontekście lekkiej niepetnosprawności intelektualnej Agnieszka Wątorek opisuje związek między sferą poznawczą a sferą językową w kontekście lekkiej niepełnosprawności intelektualnej. Obejmuje on takie zagadnienia, jak relacja mowy do myślenia oraz stan wiedzy na temat kompetencji językowych dzieci z lekką niepełnosprawnością intelektualną.

W pierwszym podrozdziale autorka przedstawia proces nabywania mowy i jego związek z myśleniem. Prezentuje poglądy Ferdinarda de Saussure'a określające język jako sumę obrazów akustycznych oraz Jeana Pigeta o czterech stadiach rozwoju intelektualnego. Autorka zestawia ze sobą dwie koncepcje, tj. determinizmu poznawczego $\mathrm{z}$ determinizmem językowym. Przedstawia koncepcję Uniwersalnej Gramatyki Chomsky'ego $\mathrm{w}$ zestawieniu z teorią przyswajania języka drogą naśladownictwa i uczenia się. W drugim podrozdziale autorka prezentuje relację mowy i myślenia a zaburzenia rozwojowe. Wyjaśnia przyczyny oligofazji, czyli zaburzeń mowy, wskazując czynniki powodujące zaburzenia językowe i komunikacyjne $\mathrm{u}$ dzieci $\mathrm{z}$ lekką niepełnosprawnością intelektualną. Wymienia problemy diagnostyczne dla zjawiska lekkiej niepełnosprawności intelektualnej, takie jak kryterium IQ niewerbalnego oznaczającego występowanie problemów językowych zarówno w niskiej, jak i w wysokiej sprawności intelektualnej. $\mathrm{W}$ podrozdziale 3 autorka wyjaśnia pojęcie niepełnosprawności intelektualnej, opierając się na Międzynarodowej Klasyfikacji Chorób i Problemów Zdrowotnych (International Classification of Diseases ICD-10 z 1994 r.), opracowanej pod auspicjami Światowej Organizacji Zdrowia WHO. Według ICD-10 upośledzenie umysłowe to istotnie niższe od przeciętnego funkcjonowanie intelektualnie zdiagnozowane przed 18. rokiem życia. W dalszej części podrozdziału przedstawione zostały narzędzia diagnostyczne stosowane $\mathrm{w}$ rozpoznaniu niepełnosprawności intelektualnej. Wymienione są tu przede wszystkim narzędzia badające poziom umysłowy dzieci, tj. Skala Inteligencji Weschlera WISC-R, Skali Stanford-Binet 
oraz Skala Leitera i Skala Dojrzałości Umysłowej Columbia. Autorka zwraca szczególną uwagę na wieloetapowość badań przy orzeczeniu niepełnosprawności intelektualnej. Przy diagnozie należy zwrócić uwagę na takie kryteria, jak ocena sprawności intelektualnej, porównanie poziomu poszczególnych funkcji, rozpoznanie zaradności życiowej, aspekty medyczne oraz pedagogiczne. W dalszych rozważaniach autorka skupia się na uwarunkowaniu rozwoju psychospołecznego dzieci z lekką niepełnosprawnością intelektualną. W podrozdziale omówiono podłoże genetyczne oraz społeczne występowania niepełnosprawności intelektualnej u dzieci. Szczególnie dużo miejsca poświęca się czynnikom wychowawczym i społecznym. Autorka wymienia niewydolność wychowawczą rodziców wśród czynników odpowiedzialnych za lekką niepełnosprawność intelektualną. W kolejnym podrozdziale Agnieszka Wątorek prezentuje właściwości procesów poznawczo-językowych u dzieci z LNI, kontynuując rozważania nad kompetencją komunikacyjną. Przedstawia wiele deficytów poznawczych (zaburzenia percepcji uwagi, pamięcią i myślenia). Podrozdział 4 nosi tytuł Przeglad badań nad kompetencja jezykowa dzieci z LNI. Zaprezentowano w nim umiejętności leksykalne, narracyjne oraz gramatyczne dzieci z LNI. W każdym z podrozdziałów autorka prezentuje koncepcję nad wybraną kompetencją. Celem omawianego podrozdziału jest przedstawienie wybranych umiejętności u dzieci z lekką niepełnosprawnością intelektualną na wybranych etapach rozwoju. Autorka rozpoczyna od poziomu umiejętności leksykalnych, przywołując badania nad słownictwem osób z LNI Sheili Glenn i Cliffa Cunninghama, a także Claudii Cardoso-Martins. Z przeprowadzonych badań wynika, że początkowa zdolność rozpoznawania słów u dzieci z lekką niepełnosprawnością intelektualną ujawnia się w tym samym wieku umysłowym, jak w całej populacji, jednak wkrótce po wspólnym starcie większość z nich zostaje w tyle. Wyniki prezentowanych badań dotyczą wczesnego repertuaru leksykalnego dzieci niepełnosprawnych intelektualnie, obejmując głównie nazwy obiektów dynamicznych, przedmiotów użytkowych, części ciała, podstawowe aktywności, cechy percepcyjne, a także pojedyncze zaimki, spójniki i przyimki. Do rzeczowników obecnych w wypowiedziach dzieci z LNI należą: nazwy osób, zwierząt, roślin i produktów spożywczych oraz przedmiotów codziennego użytku. Na rejestr czasowników natomiast obok dominujących "być" i „mieć” złożyły się zmiany położenia w przestrzenie istot żywych i czynności manipulacyjne. Kończąc opisywany podrozdział, autorka próbuje, na 
podstawie badań, ustalić wspólny model terapii mowy dzieci z LNI. Dalsze rozważania oscylują wokół nabywania kompetencji gramatycznych przez dzieci z LNI. Punktem wyjścia jest teoria o istnieniu związku pomiędzy wiekiem chronologicznym a produkcją słów. Z przedstawionych przez autorkę badań naukowych (m.in. Bruno Facona oraz Therese FaconBollengier) wynika zależność kompetencji składniowej od pamięci werbalnej. Autorka prezentuje także badania nad opanowaniem składni na gruncie polskim, powołując się na Zbigniewa Tarkowskiego i Józefę Bałachowicz. Podsumowując część sprawozdawczą podrozdziału, dotyczącą umiejętności gramatycznych, Agnieszka Wątorek zwraca uwagę na różnice w metodologii i procedurach badawczych w opisanych badaniach. Pozwala to jednakże wysnuć wniosek, iż dzieci z LNI mają największe problemy z rozumieniem konstrukcji złożonych, wykazują wybiórcze przyswajanie schematów zdaniowych, niekonsekwentne stosowanie reguł syntaktycznych oraz jednostajne produkowanie struktur określonego typu.

Agnieszka Wątorek najwięcej uwagi poświeciła umiejętnościom narracyjnym dzieci z LNI. Powołując się na badania naukowe nad zdolnościami narracyjnymi dzieci z LNI, autorka nie jest w stanie jednoznacznie stwierdzić zależności między niepełnosprawnością a narracją jednostki. Przedmiotem prowadzonych badania była zdolność do opowiedzenia historyjki z prezentowanego obrazka. Z badań wynika, że konstruowanie opowiadań sprawia dzieciom niepełnosprawnym intelektualnie duże trudności. Sprawnie rozpoznają i nazywają poszczególne postaci, przedmioty i działanie, jednak nie potrafią dokładnie nakreślić sytuacji, w jakiej znalazł się główny bohater. $\mathrm{W}$ ich relacji pojawia się wiele nieścisłości, deformacji oraz braków rekonstrukcyjnych. Zgodnie z innymi badaniami jednostki z LNI nie dostrzegają związku pomiędzy trafnością użytych przez siebie sformułowań a ich reprezentacjami w umyśle odbiorcy.

Rozdział 3 omawianej publikacji zawiera metodologię badań własnych, problematykę badawczą oraz metody i narzędzia badawcze. Przedmiotem badań autorki jest kompetencja językowa ośmio- i dziesięcioletnich uczniów szkół specjalnych oraz integracyjnych z lekką niepełnosprawnością intelektualną. Dokonuje ona charakterystyki umiejętności leksykalnych, gramatycznych i narracyjnych dzieci z LNI. Przedstawia szczegółowe hipotezy badawcze obejmujące dwie grupy, czyli dzieci z LNI oraz dzieci w normie intelektualnej. Badania przeprowadzone zostały w latach 2008-2011 na terenie dwóch dużych miast, tj. Krakowa i Katowic, a także 
w miastach sąsiadujących, na dużej grupie dzieci (187) tworzących grupę kryterialną oraz dwie grupy kontrolne (jedną dobraną ze względu na wiek umysłowy, drugą ze względu na wiek metrykalny). Badania miały charakter wieloetapowy. Pierwszy etap to badania pilotażowe dające sposobności oceny narzędzi badawczych. Autorka opisuje sposób wyłaniania uczestników oraz sposób klasyfikacji kandydatów do grupy kryterialnej. Autorka dokonała celowego wyboru badanych dzieci, przedstawiając charakterystykę badanych. W kolejnej części rozdziału opisano metody i narzędzia badawcze stosowane $\mathrm{w}$ celu pozyskiwania danych, a także wykorzystane metody jakościowe (metodę analizy dokumentów, metodę badań testowych oraz metodę studium porównawczego). Wśród analizowanych dokumentów znalazły się deklaracje zgody rodziców na udział dziecka $\mathrm{w}$ badaniu, ankiety wypełnione przez rodziców, opinie psychologiczne, pedagogiczne, medyczne o uczniach z LNI oraz pisma przedstawiające przebieg ich ścieżki zawodowej. Agnieszka Wątorek opisuje cel zastosowania danej metody badawczej oraz użyte narzędzia. Starannie przedstawia próby mierzące zasób słownictwa, poziom opanowania pojęć, umiejętności gramatyczne oraz narracyjne. Do każdego podrozdziału załącza tabele i schematy potwierdzające wyniki badań danego problemu.

Rozdział 4, 5 i 6 są kontynuacją i przedstawieniem wyników badań autorki nad poziomem umiejętności leksykalnych, gramatycznych, narracyjnych uczniów z LNI w porównaniu z badanymi o prawidłowym rozwoju umysłowym. W rozdziałach umieszczone są wyniki testów, wykresy mierzące próby oraz wyniki badań $\mathrm{w}$ świetle prezentowanych zmiennych. Wątorek prezentuje zależności między zastosowaniem danej próby a zmienną występującą w badanym zjawisku.

W ostatnim 7 rozdziale autorka przedstawia wyniki badań własnych nad kompetencją językową dzieci z lekką niepełnosprawnością intelektualną. Prezentuje odpowiedzi na hipotezy badawcze postawione na począt$\mathrm{ku}$ publikacji oraz wnioski z przeprowadzonych badań. Na zakończenie publikacji autorka proponuje model integracji dzieci niepełnosprawnych z rówieśnikami. Integracja miałaby polegać na stworzeniu optymalnego modelu kształcenia specjalnego ukierunkowanego na indywidualny rozwój dziecka z LNI. W tym celu powinno tworzyć się klasy specjalne w szkołach masowych, które działałyby na odpowiednich zasadach dostosowanych do potrzeb dzieci niepełnosprawnych. 
Podsumowując, można uznać, iż Agnieszka Wątorek podjęła się pracochłonnego zadania analizowania języka dzieci z lekką niepełnosprawnością intelektualną, uwzględniając umiejętności leksykalne, gramatyczne i narracyjne na dwóch podgrupach wiekowych ośmio- i dziesięciolatków. Jasno sformułowane hipotezy badawcze oraz staranny dobór narzędzi badawczych pozwoliły stworzyć unikalny z perspektywy jakości badań empirycznych projekt badawczy. Niewątpliwą zaletą publikacji jest zebranie i prezentacja najnowszych badań dotyczących kompetencji językowych dzieci z LNI. Wydaje się, że autorka dołożyła wszelkich starań, by omówić klasyczne teorie i najnowsze doniesienia z badań, czego dowodem może być bogata bibliografia zawierająca zagraniczne pozycje. Można odczuwać pewien niedosyt związany $\mathrm{z}$ brakiem $\mathrm{w}$ omawianej pozycji aspektów psycholingwistycznych i neurolingwistycznych oraz badań Willhelma Levetela nad wytwarzaniem mowy, a także modelu Anny Cutler i Cliftona odnoszących się do percepcji. Głównym zarzutem omawianej publikacji jest brak sformułowanego problemu głównego. Autorka szczegółowo opisuje przedmiot badań, z którego można domyślić się, jaki jest problem główny. Swoją uwagę skupia przede wszystkim na prezentowaniu hipotez badawczych.

Układ książki jest jasny i przejrzysty. Autorka posługuje się językiem specjalistycznym, jednakże bardzo klarownym, zrozumiałym dla początkującego pedagoga/logopedy. Forma prezentowanych treści w poszczególnych rozdziałach jest spójna. Autorka dzieli rozdziały na podrozdziały, nadając im tytuły odnoszące się do poruszanych $w$ danym fragmencie problemów. Ponadto, w publikacji zamieszczono załączniki w postaci testów oraz szczegółowy spis wykresów i tabel, co pozwala czytelnikowi na szybkie wyszukiwanie treści.

Reasumując, książka Agnieszki Wątorek niewątpliwie jest cennym wkładem w badania nad rozwojem mowy u dzieci z lekką niepełnosprawnością intelektualną. Efekty badań mogą być zastosowane w praktyce $\mathrm{w}$ celu stworzenia odrębnego programu nauczania uwzględniającego potrzeby dzieci z lekką niepełnosprawnością intelektualną. Publikację można polecić zarówno pedagogom, jak i polonistom, psychologom i terapeutom jako kompendium wiedzy oraz inspirację do dalszych poszukiwań badawczych. 